\title{
Toplumsal Șeytan Üçgeni: İktidar, Hegemonya ve Propaganda
}

\author{
Ayhan Biber ${ }^{1}$
}

\section{Eda Turancl ${ }^{2}$}

\begin{abstract}
Öz
Yönetim olgusunun ortaya çıktığı, iktidar ilişkilerinin yaşandığı her yerde rızanın, toplumsal meşruiyetin nasıl elde edileceği, hegemonyanın nasıl sağlanacağı, iktidar alanın nasıl genişletileceği temel bir sorundur. Otoriter toplumlarda baskı ve şiddet, iktidarın varlığı ve devamı açısından önemli bir araç olma vasfını tarihsel süreç içerisinde uzun süre korumuştur. Ancak, çoğulcu anlayışın geliştiği, demokratik kazanımların görece arttığı günümüz toplumlarında iktidarların daha çok ideolojik araçlara gereksinim duymaya başladığı görülmüştür. Totaliter yönetimlerin varlıklarını, baskı ve şiddete dayalı bir anlayışla sürdürebilmeleri mümkün iken; demokratik toplumlarda baskıya karşı gösterilen direnç, yönetimin otorite kurma tarzını değiştirmekte ve yumuşatmaktadır. Bu bağlamda; mevcut iktidara rıza gösterme olarak tanımlanan hegemonyanın kurulması açısından bilgi ve iletişim teknolojileri sayesinde sürdürülen açık ve örtülü propaganda faaliyetleri büyük önem taşımaktadır.
\end{abstract}

Anahtar Kelimeler: İtidar, Hegemonya, Meşruiyet, Propaganda.

\section{Social Devil's Triangle: Power, Hegemony and Propaganda}

\begin{abstract}
How consent will be obtained, social legitimacy will be won, hegemony will be achieved and the power domain will be expanded is the main problem in anywhere that the phenomenon of management has arisen and the power relations are experienced. In the authoritarian societies, the oppression and violence have maintained their characteristics of being important means for the existence and continuance of the power for a long time during the historical process. However, it is seen that the powers have started to be in need of more ideological means in the presentday societies in which pluralistic understanding has developed and democratic acquisitions have enhanced. Although, it is possible for totalitarian regimes to continue their existences only through an understanding based on oppression and violence; the resistance against the oppression changes and softens the administration's way of establishing authority in democratic societies. In this context, explicit and implicit propaganda activities carried on thanks to the information and communication technologies have great importance in terms of establishing hegemony which is defined as showing consent to the current power.
\end{abstract}

Keywords: Power, Hegemony, Legitimacy, Propaganda.

1 Prof. Dr. Gazi Üniversitesi, İletişim Fakültesi..

2 Arş. Gör. Gazi Üniversitesi, İletişim Fakültesi. 


\section{Giriș}

i

ktidar olgusunun ortaya çıkmasına koşut olarak, gücün, otoritenin, yönetme erkinin ne şekilde meşru kılınacağına ilişkin sorunların ve bu sorunların çözümüne yönelik arayışların belirginlik kazandığı görülmektedir. Yöneten-yönetilen ayrımının olduğu her yerde, iktidarın nasıl elde edileceği, nasıl sürdürüleceği siyaset felsefesi, siyaset sosyolojisi kapsamında tartışılan temel meselelerdir.

Totaliter, baskı ve şiddeti yöntem olarak benimsemiş toplumlarda sorun çok karmaşık değildir. Neyin, hangi uygulamaların halkın "yararına" olduğunu en iyi kendilerinin bildiğini sanan iktidar sahipleri, bu uygulamaları halka rağmen sürdürmekte bir sakınca görmez, bununla birlikte halkın kafasının üzerine inmeye hazır bekleyen bir sopayı da asla eksik etmezler (Chomsky, 2008: 7). Ancak, sivil alanın görece geniş olduğu, çoğulcu bir nitelik kazanmış demokratik toplumlarda baskı ve şiddet geçerliliğini kaybetmekte; otoriteye, baskıya direnç gösteren örgütlenmeler ortaya çıkmaktadır. "Yeni Dünya Düzeni"nde bildik anlamdaki otoriter sistemlerin varlıklarını sürdürebilmeleri zorlaşmakta, buna bağlı olarak otoritenin tarzı değişmekte ve yumuşama eğilimi göstermektedir. Bu süreçte, gücün meşrulaştırılması veya Gramsci'nin (2009: 153) mevcut iktidar ilişkilerine rıza gösterme şeklinde tanımladığı hegemonyanın sağlanması açısından bilgi ve iletişim teknolojilerinin tüm olanakları seferber edilerek yürütülen propaganda kapsamındaki çalışmalar büyük önem taşımaktadır.

Yukarıdaki tespitlerden hareketle tasarlanan bu çalışmada; çoğulcu nitelik kazanmış demokratik toplumlarda hegemonyanın ne anlama geldiğini tartışmak, iktidarın gereksinim duyduğu rızanın inşası, sosyolojik anlamda meşruiyetin sağlanması, farklı bir ifadeyle; hegemonyanın oluşturulması sürecinde, örtülü veya açık propaganda kapsamında ne tür çalışmalar yapıldığını ortaya koymak ve medyanın bu süreçte ne tür roller üstlenebileceğini belirlemek amaçlanmıştır.

\section{1. İktidar Olgusu ve İktidarın Dayanakları}

Toplumsal yaşamın ortaya çıkışına paralel olarak kendisini gösteren ve siyasal alanda tartışmaların merkezine oturan iktidar olgusu, siyaset felsefesi ve siyaset sosyolojisinin temel çalışma alanlarından birisi olmuştur. İktidarın tanımı kadar iktidarın kaynağına ilişkin tartışmalar, uzun süredir yürütülmekte ve pek çok disiplin tarafından değişik açılardan ele alınmaktadır. Özellikle toplumsal değişim süreçlerine ve toplumsal farklılıklara paralel olarak ortaya çıkan farklı iktidar ve yönetim biçimleri, iktidarın dayanaklarına ve yöneten ile yönetilen arasındaki ilişkiye ilişkin tartışmaları da çeşitlendirmektedir. Bu nedenle, her dönem güncelliğini koruyan iktidar kavramı, akademik, siyasal ve toplumsal çok sayıda tartışmanın ve çalışmanın konusunu oluşturmuştur.

Siyasal açıdan iktidar kavramı, genel olarak güç, otorite ve kontrol gibi kavramlarla bir arada düşünülmektedir. Hangi toplumsal ve siyasal sistem açısından değerlendirilse değerlendirilsin, farklı biçim ve derecelerde, iktidarın güç ve otorite üzerine kurulduğu görülmektedir. Buna göre her toplumsal yapı, kendi otorite pratiklerini, kontrol mekanizmalarını ve baskı dinamiklerini yaratmakta ve sürdürmektedir. Yöneten ve yönetilen ayrımının olduğu her toplum, bir anlamda kendi iktidarını şekillendirmekte ve bireyler bu iktidara boyun eğmektedir. Bu açıdan bakıldığında, en demokratik toplumlarda bile, bir kontrol mekanizmasının varlığından söz etmek mümkündür.

İktidar, üzerine pek çok tanımlamanın yapıldığı bir kavramdır. Çok farklı biçimlerde ifade edilebilecek olan kavram, temel olarak "toplumsal bir ilişki içerisinde bulunan bir kişinin 
başkalarından buyruklarına uymalarını talep etme hakkına sahip" (Duverger, 2011: 129) olma durumuna gönderme yapmaktadır. Bu tanım, iktidar ve otorite arasındaki ilişkiyi açıkça göstermektedir. Siyasal iktidarı, "meşrulaştııımış güç kullanma kabiliyeti" olarak da tanımlayan Friedman'a (1990: 60) göre ise iktidar; baskı, güç, manipülasyon, ikna, rıza gibi kavramlar üzerinden kendisini ifade etmekte ve tanımlamaktadır. İktidarın kendini tanımlarken referans aldığı kaynaklardan da anlaşılacağı gibi kendine uydurma, kendine tabi kılma ve otorite kurma niteliği iktidarın en temel özelliklerini oluşturmaktadır. İktidarlar ancak, emir vermek, buyurmak ve boyun eğdirmek hakkına sahip oldukları durumlarda var olabilmektedirler. Dolayısıyla, bu eşitlikçi olmayan ilişkilerin resmen kurulmuş ve kurumsallaşmış olması gerekmektedir (Duverger, 2011: 131). İktidarlar bu açıdan; ister baskıcı ve totaliter, ister demokratik rejimlerde olsun her zaman bir kontrol ve otorite yetkisine sahip olmaktadırlar. Yönetimler açısından farklılık gösteren nokta ise; yönetme biçimleri ile otoritenin kurulma, sürdürülme ve uygulanma biçimleridir.

İktidarların kendilerini var etme biçimlerinde ortaya çıkan farklııklar ise, bazı temel soruların yanıtlanmasını gerekmektedir. Bu bağlamda; iktidarın kendi iradesini bireylere nasıl kabul ettirdiği, bireylerin rızalarının nasıl elde edildiği ve bir iradeye boyun eğmiş bireylerin başkalarının tercihlerini nasıl kabul ettikleri gibi sorular karşımıza çıkmaktadır (Galbraith, 2004: 12-13).

Totaliter rejimlerde ve baskıcı yönetimlerde, doğası gereği şiddete ve zora dayanan uygulamalar ve yaptırımlar, bireylerin hareket ve eylem alanlarını belirli sınırlarla çevirmektedir. Bu yönetimlerde baskı ve şiddet temelli bir iktidar ve yönetim anlayışı yaygındır. Bu açıdan totaliter rejimlerdeki sivil alanı kısıtlayıcı anlayış sayesinde, iktidarı oluşturmanın ve sürdürmenin görece daha kolay olduğu düşünülmektedir. Buna göre, egemen ideolojinin baskıcı ve dayatmacı tutumu, bireylerin karar alma mekanizmalarında etkili olmaktadır. Totaliter veya baskıcı rejimlerde, toplumun yanlış kararlara dayanarak hareket etmelerine imkân vermemek, bu anlamda toplumun çıkarları açısından en iyinin yargısına varabilmek egemenlerin elindedir. Bu güç iktidara, toplumun genelinin kafalarının üstünde bir sopayı hazır bekletmek ve yoldan çıkıldığı takdirde onu kullanmak yetkisini de vermektedir (Chomsky, 2008: 7). Ancak bu durum, görece özgürleşmiş, sivil alanın genişlemiş olduğu demokratik rejimlerde her zaman bu kadar kolay değildir. Bu tür toplumlarda artık baskıcı güç kaybedilmiştir, bu nedenle demokratik yönetimlerde, totaliter devlette copun gücüne denk gelen propaganda tekniklerine yönelmek gerekmektedir. Chomsky'nin ifadesiyle (2008: 7); "totaliter devlette cop neyse demokraside de propaganda odur". İşte bu yargı, demokratik toplumlarda propagandanın, egemen ideoloji ve iktidar açısından önemini de açıkça ortaya koymaktadır. Bu açıdan demokratik anlayışlarla birlikte, baskı ve tahakkümden uzaklaşan ama rıza ve ikna kurmaya dayalı bir anlayışı her geçen gün daha çok benimseyen bir yönetim mekanizması gelişmektedir. Bu durum, yönetimlerin kendilerini meşru kılma ve meşruiyetlerini kabul ettirme zorunluluklarını da ortaya çıkarmaktadır. Böylece egemen ideolojinin gücü, ancak rıza gösterilmesi durumunda meşru hale gelebilmektedir.

Bu noktada, meşruiyet ve rıza yaratma süreci ile egemen ideoloji arasındaki ilişkinin kurulması ve anlaşılması açısından Gramsci'nin hegemonya kavramına başvurmak gerekmektedir. Hegemonya kavramı, "kapitalist toplumsal formasyonlardaki egemenlik ve iktidar süreçlerini anlamak amacıyla kullanılan önemli bir kuramsal araç" (Yetiş, 2012: 97) konumundadır. Özellikle rıza ve uzlaşmaya dayalı bir anlayışa gönderme yapan kavram, demokratik yönetimlerin kendi meşruiyetlerini ve egemen ideolojilerini kurma, benimsetme ve sürdürme sürecinde iktidarın dayanaklarını anlamak açısından önemlidir. Bu nedenle, hegemonya ve iktidar arasındaki ilişkinin açık olarak tanımlanması gerekmektedir. 


\section{Hegemonya}

İktidarın dayanakları ve iktidarın sürdürülme biçimi incelenirken, özellikle Gramsci'nin tanımladığı ve çalışmalarında ortaya koyduğu anlamıyla hegemonya kavramına başvurmak yol açıcı olmaktadır. Egemenlik ve iktidar ilişkilerine doğrudan gönderme yapan ve bu ilişkilerin sürdürülmesi ve üretilmesi süreçlerine ışık tutan kavram, bugün iktidarı ve iktidarın özelliklerini anlamak açısından anahtar bir rol üstlenmektedir. Bu nedenle, rıza ve onaya dayalı bir iktidar kurma düşüncesi üzerinden temellenen kavram, özellikle 20. yüzyılda pek çok disiplin açısından anlamlı hale gelmiş, pek çok çalışmanın ve tartışmanın da merkezine oturmuştur.

Gramsci'nin özellikle "Hapishane Defterleri” adlı eserinde geliştirdiği ve tanımladığı hegemonya kavramı, siyasal iktidar açısından "kendiliğinden oluşan rızanın" örgütlenmesine (Hall vd., 1985: 12) gönderme yapmaktadır. Gramsci kavramı, Batıdaki burjuva iktidarlarının yapısını (Anderson, 2007: 40) anlamak ve incelemek için kullanmıştır. Temel olarak güç ilişkilerini ve bu ilişkilerin ortaya çıkan somut biçimlerini incelemek için kullandığı kavram, Gramsci'nin en tartışmalı kavramlarından da birisidir (Crehan, 2006: 146). Bu açıdan bakıldığında siyasal hegemonya; klasik anlamda baskıya ve zorlamaya dayanmayan, tahakkümden farklı, rızanın etrafında biçimlenen bir iktidar kurma biçimine işaret eder. Farklı bir ifadeyle, "toplumsal sınıflar ya da gruplar arasındaki, kendiliğinden rızaya dayalı ideolojik üstünlük, denetim ve yönlendirme ilişkilerini anlatır” (Yetiş, 2012: 87).

Gramsci'nin hegemonya kavramı, günümüz iktidar ilişkilerinin, otorite kurma biçimlerinin anlaşıması açısından önem taşımaktadır. Özellikle klasik baskı kurma biçimlerinin işe yaramadığı gelişkin kapitalist toplumlarda, egemenliğin sadece tahakkümle sürdürülemeyeceği tespitinden hareket eden Gramsci, toplumsal egemenlik ve siyasal iktidar süreçlerinin rıza ve zorlamanın özgül bileşimlerinden oluşturulması gerektiğini vurgulayarak, kavramı yeniden şekillendirme çabasına girişmiştir (Yetiş, 2012: 88). Doğrudan baskının ve zorlamanın artık sivil direnişle karşıllaştı̆̆ı demokratik toplumlarda, "hegemonya her şeyden önce zor (negatif) ve rızayı (pozitif) aynı potaya sokarak" (Şengül, 2012: 52) bu yönetimlerin egemenlik anlayışlarını tanımlamayı mümkün kılmaktadır.

Özellikle sivil alanın genişlediği ve toplumsal yapının çoğulcu bir nitelik kazandığı demokratik toplumlarda, iktidarı yalnızca bir siyasal unsur olarak görmemek; siyasal iktidarın dışındaki iktidar alanlarını da incelemek gerekmektedir. Çünkü egemen ideoloji daha geniş alanlarda rıza yaratmak durumundadır. Bu açıdan, Gramsci özellikle hegemonya kavramını, iktidarı ve iktidarın dayanaklarını siyasal, ekonomik ve ideolojik düzeylerdeki yansımalarını da dikkate alacak şekilde daha bütünsel bir bağlama yerleştirmektedir (Yetiş, 2012: 89). Böylece iktidar, kendisini sadece siyasal arenada göstermekle kalmayarak, toplumun daha geniş bir zeminine yayılacaktır.

Gramsci, Lenin'den ödünç aldığı ancak O'nun daha çok siyasal düzey ile sınırlandırdığı kavramı, sivil toplum alanını da ele alacak biçimde genişletmiştir (Hall vd., 1985: 13). Bu açıdan bakıldığında hegemonya kavramının sosyopolitik bir durumu ifade ettiği; sadece siyasal bir olgu olmadığı, aynı zamanda içerisine sosyal, ekonomik ve kültürel, bütün bir sistemi dahil ettiği görülmektedir. Bu bağlamda hegemonya, siyasal arenanın yanı sıra "okullar, cadde şekilleri ve isimleri, mimari, aile, işyeri ve kilise gibi çeşitli” toplumsal alanlarda da (Morton, 2011: 135) üretilmektedir. Böylece, hegemonya mücadeleleri ve iktidar ilişkileri, devlet dışı alanlarda da kendini göstermektedir (Şengül, 2012: 52). Egemen ideoloji, yalnızca siyasal bir olgu olarak değerlendirilmediğinden iktidar pratikleri de değişmekte, yeni uygulama biçimleri ortaya çıkmaktadır. 
Toplumların çoğulcu bir yapıya kavuşması, demokratik kazanımların artması; iktidar gruplarının, hegemonya uygulayacakları farkı kesimlerin çıkar ve eğilimlerini dikkate alarak, karşılıklı ve dengeli bir uzlaşma (Anderson, 2007: 37) kurmalarını gerektirmiştir. Bu açıdan iktidarın baskıcı ve zora dayanan eylemlerinin artık mümkün olmadığı siyasal rejimlerde, iktidarı kurmanın en temel dinamiği hegemonik bir düzen çerçevesinde, "kendiliğinden rıza süreçleriyle yaygınlık kazanan egemen sınıf ideolojisinin toplumda 'ortak duyu' haline" (Yetiş, 2012: 89) gelmesiyle mümkün olmaktadır. Böylece egemen sınıf ideolojisi, toplumda iktidar odaklarının ve hegemonik düzenin de temel dayanaklarını oluşturur.

Özellikle sivil alanın görece genişlemiş olduğu demokratik toplumlarda, iktidarın sürekliliğinden bahsedilemediği gibi, hegemonyanın da sürekliliğinden bahsetmek kolay değildir. Hegemonya, iktidarın devamlılığı için sürekli olarak yeniden inşa edilmek durumundadır. Buna göre, "toplumsalsiyasal egemenlik ve iktidar biçimlerinin durağan olmaması nedeniyle, hegemonya değişen koşullara bağıı olarak sürekli yeniden tahkim edilmek zorundadır” (Yetiş, 2012: 93). Bu nedenle rızanın, ortak duyular ve uzlaşma üzerinden sürekli olarak yeniden kurulması gerekmektedir. Gramsci'ye göre hegemonya, hiçbir zaman tamamlanmış bir durum değildir, bunun aksine hakim sınıf hegemonyasını kültürel, ahlaki ve politik liderlik ile bir oranda zorlamayı kullanarak sürdürmektedir. Ezilenlerin ezenlere gösterdiği rıza, hiçbir zaman otomatik değildir (Lodziak, 2003: 29). Her zaman yeniden kurulmaya intiyaç duymaktadır. Bu açıdan, egemen ideolojinin varlığı ve iktidarın sürekliliği ancak, rıza ve oydaşma temelinde meşruiyetini sağlamasıyla mümkündür. Aksi halde varlığını koruması mümkün değildir.

\section{3. İktidar-Meșruiyet İlișkisi ve Hegemonyanın Olușturulması}

Bir başkası üzerinde kontrol kurabilme pratikleri günümüz toplumları ve siyasal sistemleri açısından farklılıklar göstermektedir. Özellikle, iktidarlarını baskı ve zorlamaya dayandıran totaliter rejimlerden farklı olarak günümüz kapitalist demokratik yönetimleri, geleneksel anlayıştan farklılaşan iktidar ve egemenlik kurma yöntemlerini benimsemişlerdir. Böylece, iktidardaki geleneksel baskıcı anlayış azalmış, bunun yerine gücünü ve iktidarını meşruiyetinden alan yönetim biçimleri tarih sahnesine çıkmıştır.

İktidar ve meşruiyet arasındaki ilişki, özellikle demokratik yönetim anlayışında önem kazanmıştır. Buna göre, iktidarını baskı ve zorlama üzerine kurmayan yönetimler, daha rasyonel, daha kabul edilebilir meşruiyet dayanaklarına gereksinim duymaya başlamış ve meşruiyetlerini sağlayacak uygulamalara yönelmişlerdir. Meşruiyet konusu siyasal açıdan değerlendirildiğinde, egemen iktidara rıza gösterme ve iktidarın kabulü anlamına gelmektedir. Bu açıdan meşruluk kavramı "yönetsel erkin dayanaklarının değerlendirilmesinde gündeme" (Gürbüz, 1998: 4) gelmiş bir kavramdır. Meşruiyet sorununu siyasal anlamda, "siyasal iktidarın kendisini ve eylemlerini topluma kabul ettirme” (Çetin, 2003: 66) sorunu olarak görmek mümkündür. Buna göre, zorlayıcılığa dayalı iktidar biçimlerinden farklı olarak, özellikle geniş sivil alanlara sahip çoğulcu demokratik sistemlerde iktidarlar, zorlayıcı güce nadir olarak başvurmakta ve yaptırımda bulunma tehdidi iktidar kurmada ancak ikinci derecede bir rol oynamaktadır (Duverger: 2011: 124).

Rıza oluşturma sorunu ve pek çok devletin kendi meşruiyetlerini bir biçimde yönetilenlerin rızasına dayandırmaları gerektiği anlayışı, çağdaş siyasal yaşamın asli bir öğesi olmakla birlikte, çağdaş siyaset sosyolojisi ve politika kapsamında yürütülen çalışmaların da önemli konularından birisi haline gelmiştir (Buci-Glucksmann, 2012: 121). Özellikle 18. yüzyıldan itibaren siyasal, sosyal ve kültürel alanda yaşanan dönüşümler, Batı'da yaşanan devrimler, yönetim anlayışında 
ortaya çıkan yeni yaklaşımlar, teknolojinin ve toplumsal yaşantıdaki farklılaşmalar ile kitle iletişim araçlarının gelişimi iktidar odaklarının zihniyet dünyasını, anatomisini, yapısını değişime, dönüşüme zorlamaya başlamıştır. Buna göre, yöneten ve yönetilenler arasındaki keskin ayrımlar ortadan kalkmaya başlamış; yönetenler, yönetilenlerin rızasını almak ve iktidarlarını meşru kılmak zorunda kalmışlardır. Bu bağlamda, özellikle çağdaş toplumlarda ortaya çıkan meşruiyet sorunu iktidar odakları ve iktidar mücadelesi etrafında şekillenmektedir. Daha çok sivil alanın genişlediği demokratik toplumlarda, iktidarların meşruiyetlerini kazanma intiyacı özellikle kendini göstermektedir. Bu açıdan bakıldığında demokratik rejimler ile meşruiyet arasındaki ilişki, rıza ve onay temelinde kurulabilmektedir. Eğer iktidarlar, onay ve rıza yerine zor ve baskı üzerine kuruluyorsa o zaman meşruiyetin varlığından söz etmek mümkün değildir. Rıza üzerine kurulmayan bir siyasal iktidar toplumsal anlamda meşru kabul edilemez. Meşruiyet kaynağının güce dayandırıması ve toplumu zorla itaat ettirecek araçlara sahip olunması yalnızca baskıcı bir gücün varlı̆̆ına işaret etmekte ve bu güç ise zorbalık veya diktatörlük olarak tanımlanmaktadır (Çetin, 2003: 70).

Meşruiyet egemen bir sınıfın varlığıyla anlamlı hale gelmektedir. Dolayısıyla, yönetenin olmadığı yerde meşruiyet kavramına da ihtiyaç duyulmamaktadır. Aynı zamanda meşruiyet; egemenliğe, başka bir ifadeyle Gramsci'nin yöneten sınıfların toplumsal uzlaşma yani rıza sağlama biçimi olarak tanımladığı hegemonyaya bağlıdır (Kazancı, 2002: 74).

Meşruiyet, süreklilik gösteren bir durum değildir. Her seferinde yeniden inşa edilmesi gereken, kazanıldığı kadar korunması için de çaba gerektiren bir durumdur (Biber, 2003: 44). Meşruiyeti otoriteye tabi olanlarca beslenen inanç karşılığında kullanan Weber, kavramın anlam çerçevesini genişletmiş, meşru otorite için farklı dayanaklar önermiştir (Kapani, 1998: 89).

Siyasal erki elinde bulunduranların, "kendi iktidarlarına meşruluk kazandırmak amacıyla başvurdukları önemli araçlardan birisi ideoloji olgusudur" (Gürbüz, 1998: 9). Buna göre, iktidarın kurulmasının ve sürdürülmesinin, egemen ideolojinin topluma yayılmasıyla ya da toplumun bu egemen düşünce yapısına rıza göstermesiyle de sağlanabileceğini söylemek mümkündür. Aynı zamanda egemen ideolojiye karşı gösterilen rıza, toplumsal bütünlüğün sağlanması açısından da önem taşımaktadır. Lodziak'ın açıkladığı gibi Gramsci (2003: 28)'nin bu anlamda tanımladığı hegemonya düşüncesi aslında egemen ideoloji açısından, toplumu birbirine bağlamakta, bütünleştiren bir olgu olarak hareket etmekte ve tüm kurumları yeniden yapılandırmaktadır. Böylece ideolojinin meşrulaştırma aracı olarak kullanılması durumu, ideoloji aracılığıyla egemen politik sistemin, toplumu oluşturan bireylerin zihinlerine yerleştirilmesi ile gerçekleştirilmektedir (Gürbüz, 1998: 10).

Gramsci'nin egemen ideolojinin yaygınlaşması düşüncesine paralel bir bakışa Althusser'de de rastlamak mümkündür. Bu açıdan, Althusser (2010) bir yandan ideolojik aygıtlarla bir yandan da baskı aygıtlarıyla egemen iktidarın varı̆̆ını sürekli olarak korumakta ve inşa etmekte olduğunu açıklamaktadır. Devletin ideolojik aygıtları temelde, toplumsal rızanın yeniden üretimini ve böylece hegemonyanın oluşturulmasını sağlamaktadır. Buna göre, hem Gramsci hem de Althusser, "ideolojinin maddi temeline vurgu yaparak, egemen ideolojiye bir iktidar kazandırmıştı" (Lodziak, 2003: 28).

İktidar ve meşruiyet arasındaki ilişki demokratik toplumlarda ve modern yönetim anlayışında giderek önem kazanan bir ilişki haline gelmiştir. Bu açıdan bakıldığında toplumsal açıdan onay ve rıza almanın öncelikli yolu meşruiyet dayanaklarının kurulmasından geçmektedir. Buna göre, “iktidarı iktidar yapan meşruluğudur” (Duverger, 2011: 128) ve özellikle meşruiyetini sağlayamamış 
yönetimlerin varlıkları tehlikeye düşmektedir. Iktidarın meşruluğu temel olarak "onun, topluluk üyeleri ya da hiç değilse bunların çoğunluğu tarafından, bir iktidar olarak tanınmış olması"dır (Duverger, 2011: 132). Bu açıdan bakıldığında, kendi meşruiyetini sağlayamayan iktidarların yönetim araçlarını ellerinde tutmaları hususunda sorunlar baş göstermektedir. Bu noktada denebilir ki, iktidarın meşruluğu ancak, onun meşruiyeti konusunda bir fikir birliği varsa ortaya çıkmaktadır. Böylece bir iktidar meşruiyetini sürdürebildiği oranda varlık gösterebilmektedir, aksi takdirde iktidar olmaktan çıkmaktadır. Bu durumda kendisine boyun eğdirmeyi sürdürebildiği oranda iktidarın devamlılığı sağlanabilmektedir (Duverger, 2011: 132).

İktidarın meşruiyetini kurma çabası, aynı zamanda iktidarın rasyonel bir tabanı olması genel kabulüne (Forti, 2000: 7) dayanmaktadır. Toplumun genel sistem ve düzenine uymayan iktidarların özellikle demokratik toplumlarda sarsılması ve engellenmesi söz konusu olabilmektedir. Bu nedenle iktidar toplumsal düzenin dışında bir unsur olarak görülmemelidir. Her iktidar içinde bulunduğu toplumsal düzeni etkilediği gibi, doğrudan ondan etkilenerek şekillenmekte ve üretilmektedir. Bu açıdan bakıldığında iktidarın tek kaynağı "o iktidarın uygulandığı topluluğun norm ve değerler sistemince saptanan meşruluk şemasına uygun olması ve bu şema konusunda da o toplulukta bir görüş birliğinin bulunmasıdır” (Duverger, 2011: 132). Bu durum özellikle görece olarak daha esnek otorite, baskı ve güç odakları bulunan demokratik toplumlarda daha belirgin bir biçimde karşımıza çıkabilmektedir. Toplumsal açıdan kabul görmeyen ya da meşruiyetini sağlayamamış iktidarların bulundukları zemin daha kaygan olabilmektedir.

Tarihsel açıdan bakıldığında, iktidar farklı biçim ve derecelerde karşımıza çıkabilmektedir. Toplumsal ve siyasal sistemlere paralel olarak gözlemlenebilen bu farklılık aynı zamanda iktidarın baskı araçlarında da farklılaşmaya gidilmesine sebep olmaktadır. Buna göre, Galbraith (2004: 14) iktidarın açık seçik üç analiz aracı olduğunu söylemekte ve bunları "caydırma, ödüllendirme, ikna ya da şartlandırma" olarak isimlendirmekte ve açıklamaktadır.

Caydırıcı iktidar, kendine boyun eğdirilmesine yönelik uygulamaları kapsar, sonuçları açısından sıkıntılı ya da sorunlu durumlar ileri sürerek bireylerin karar alma ve eyleme geçme mekanizmalarında etkilidir. Daha açık bir ifadeyle caydırıcı iktidar, olumsuz sonuçlara gönderme yaparak bireylerin itaatini sağlamaktadır. Ödüllendirici iktidar ise bunun aksine, bireylere pozitif sonuçlara gönderme yaparak yönlendirmede bulunmakta ve itaati belli bir ödülle yapmaktadır. Ancak her iki durumda da, bilinçli bir biçimde iktidara itaat etme söz konusudur. İkna etme yönteminde ise, en temelde eğitim yoluyla bireylere uygun ve doğru görünen şeyler yaptırılmaktadır. Buradaki en temel farkııık, tercihli bir seçime dayanan itaatin kişiler tarafından farkında bile olunmamasıdır. Bu açıdan bakıldığında ikna edici iktidar, gerek kapitalist ülkelerde gerekse de sosyalist ülkelerde otorite ve güç odaklarının çıkarları açısından, özellikle ekonomik ve politik mekanizmaların işleyişinde önemli rol oynamaktadır (Galbraith, 2004: 14-15).

İktidar siyasal açıdan süreklilik arz etmemektedir. Buna göre, özellikle baskı ve otorite dayanaklarının görece esnek olduğu demokratik toplumlarda iktidar meşruiyetini sağlayabildiği oranda iktidar olarak kalabilmektedir. Ancak kendi meşruiyet dayanaklarını sağlayamayan, otoritesini ve gücünü topluma kabul ettiremeyen ya da toplumsal düzene ve değerlere ters düşen iktidarların yerinden edilmesi mümkündür. Buna göre denebilir ki; ne iktidar ne de meşruiyet olgusu süreklilik gösteren durumlar değildir. Günün koşullarına, zamanın ruhuna göre yeniden inşa edilmeleri, biçimlendirilmeleri gerekir (Biber, 2003: 44). Sonuç olarak, bir yandan meşruiyetin dayanaklarının değiştiği, diğer yandan da Galbraith'in (2004: 13) belirttiği gibi, bu dayanakların topluma aktarıması ve kabul görmesini sağlayan ile buyruk altına alınmayı mümkün kılan araçlar kadar, gücün kaynağının da geliştiği ve değiştiği göz ardı edilmemelidir. 


\section{1. İktidarın Meșruiyet Aracı: Propaganda}

Psikoloji ve sosyoloji gibi sosyal bilimlerin bulguları üzerine inşa edilen sistematik ve planlı propaganda çalışmaları günümüz toplumlarına özgü olsa da; propaganda olgusuna ilişkin bir nüvenin çok belirgin izlerini, iktidar ilişkilerinin var olduğu çok eski toplumlarda bile görmek mümkündür. Bilinen ilk planlı ve kapsamlı propaganda çalışmaları Hıristiyanlığın yayılması ile ilgilidir. Propaganda sözcüğü de zaten "yayılması gereken" anlamına gelen Latince propagand kökünden gelmektedir. 30 yıl savaşlarının devam ettiği 1622 yılında Papa XV Gregory, Hıristiyanlığın yayıımasını sağlamak amacıyla İnancı Yayma Meclisi anlamına gelen "Congregatio de Propaganda Fide" adında bir birim oluşturarak, Hıristiyan olmayan ülkelere misyonerler göndermiş̧ir. Bu misyonerler çeşitli propaganda teknikleri kullanarak değişik coğrafyalarda kendi inançlarını yaymaya çalışırken kavram tarihsel süreçte ilk kez bir yazılı metinde kullanılmıştır (Pflaum ve Pieper, 1993: 407; Pratkanis ve Aronson, 2008: 12).

Propaganda kavramının yaygın kullanım kazanmasının ise yirminci yüzyılın başında gerçekleştiği söylenmektedir (Pratkanis ve Aronson, 2008: 12). Ele geçirilen iktidar alanına meşruiyet dayanakları sağlamak amacıyla yürütülen kapsamlı propaganda çalışmaları Fransız intilali ile başlamış, Bolşeviklerin çalışmaları ile önemli bir noktaya ulaşmış, Hitler'le "zirve" yapmıştır. Ancak, bu "zirve" noktası aynı zamanda siyasal propagandayla ilgili algılamaların değiştiği, kötü çağrışımların ortaya çıktığı bir nokta anlamına da gelmektedir. Çünkü Hitler ve ekibinin yürüttüğü propaganda çalışmaları nedeniyle I. Dünya Savaşı'ndan yenik çıkmış ve gururu incinmiş Almanya, Hitler'in peşine takılarak insanlığın büyük bir trajedi yaşamasına, büyük acılar çekmesine, birçok devlet arasındaki siyasal, ekonomik, sosyal ilişkilerin bozulmasına neden olmuştur.

O güne kadar görülen en büyük savaş olan I. Dünya Savaşı boyunca propaganda kavramı, "hem aldatmaca hem de karşılıklı söylenen yalanlar hem de bir eylem biçimi olarak" algılanmış ve kullanılmıştır. Özellikle savaş sırasında başta basın olmak üzere propaganda amacıyla kullanılan telefon ve fotoğraf gibi araçlar, II. Dünya Savaşı sırasında da benzer amaçlarla Almanlar tarafından kullanılmıştır (Akarcalı, 2003: 50). Özellikle radyonun da aktif bir biçimde kullanılmasıyla, iletişim araçlarının propaganda faaliyetleri üzerindeki rolü giderek daha açık hale gelmiştir.

II. Dünya Savaşı'nın ise propagandanın "gerçek eylem alanıı” bulduğu dönem olduğunu söylemek mümkündür. Buna göre, savaş sırasında ve sonrasında propaganda Bakanı Goebbels tarafından kavrama ve propaganda uygulamalarına yeni boyutlar ile açılımlar getirilmiştir. Goebbels'in başkanlığında kurulan "Halkı Aydınlatma ve Propaganda Bakanlığı" ile yeni bir propaganda dönemine girilmiş ve böylece, daha önce benzeri görülmemiş bu bakanlık ile Alman politikasında propagandaya önemli bir verilmiş, propagandaya meşru bir zemin sağlanmıştır (Akarcall, 2003: 6-7).

Kavramın tarihsel süreçte ortaya çıkışına ve edindiği olumsuz anlamlara rağmen, propagandanın sadece otoriter rejimlere özgü bir yöntem olduğunu düşünmemek gerekmektedir; çünkü propaganda olgusu, siyasal rejimlere göre yalnızca biçimsel ve düzeysel farklılıklar göstermektedir (Tolan, 1996: 454). Bu açıdan denebilir ki, her siyasal rejim örtük ya da açık bir biçimde kendi propaganda faaliyetlerini yürütmektedir. Benzer bir biçimde Chomsky de propagandanın her türlü yönetim biçiminde var olduğunu açıklamak amacıyla, Bernays'ın propaganda kavramına gönderme yapmakta ve Bernays'ın "Propaganda" eserinin kamusal ilişkiler sektörünün el kitabı olduğunu ve eserinde "kitlelerin örgütlü davranış ve fikirlerinin bilinçli manipülasyonunun, demokratik toplumun merkezi özelliği olduğunu anlatarak" başladığını söylemektedir. Aynı zamanda Chomsky (2003: 
211) kontrolün, demokrasinin en temel özelliği olduğunu da belirtmektedir. Buna göre, yönetimsel kontrolün ve bu amaçla yürütülen propaganda faaliyetlerinin sadece otoriter yönetimlere özgü bir durum olmadığı açıkça görülmektedir.

Özellikle demokratik toplumlar açısından propaganda "rıza üretimi"nin en temel araçlarından biri olarak görülmekte, iktidarın meşruluğunu sağlayacak rızanın oluşturulmasında güçlü ve etkili bir yöntem olarak değerlendirilmektedir. Buna göre Chomsky'nin (2008: 3) belirttiği gibi, "rıza üretimi" amacıyla propagandanın yeni yöntemlerle uygulanması, halkın istemediği şeylerin bile kabul ettirilmesi amacıyla kullanılmaktadır.

Propaganda en temel amacıyla ikna etme, rıza yaratma veya rıza gösterme gibi amaçlara yönelik olarak gerçekleştirilmektedir. Ancak özellikle siyasal rejimlerde yaşanan değişimler göz önünde bulundurulduğunda modern demokratik toplumlarda propagandaya duyulan intiyacın nedenleri daha da anlaşılır olmaktadır. Buna göre, iktidarı kurmaya veya sürdürmeye yönelik yapılan propaganda faaliyetleri, bireyleri rıza ve iknaya yönelik çalışmalar olup, "demokrasiler de dahil her türlü siyasal sistem içerisinde gerçekleşmektedir” (Bektaş, 2002: 19). Ancak baskıcı rejimlerde iktidarı kurmak ve sürdürmek baskı ve zor kullanma ile mümkün iken, günümüz demokratik rejimlerinde propaganda faaliyetleri gibi başka yollara başvurulmaktadır.

Propagandayı herhangi bir siyasal sistemin eğitim faaliyetlerinden, televizyonda veya radyoda sunulan "objektif" bir haberden ayrı düşünmek olanağı yok gibidir. Dolayısıyla, propagandayı sınırları belirgin bir kavramsal çerçevenin içine oturtmak bir hayli zordur. Propaganda kavramını Ellul, "psikolojik bakımdan bütünleştirilmiş ve belirli bir düzen içerisinde yapılaşmış bir kitlenin eyleme katılmasını sağlamak amacıyla, örgütlenmiş bir grubun psikolojik araçlardan yararlanarak uyguladığı yöntemlerin bütünü” (Tolan, 1996: 455) olarak tanımlamaktadır. Bir başka tanımda ise, iletişim alanında yaşanan teknolojik gelişmeler ile propagandanın "modern toplumlarda bir iletişim biçimi olarak" kabul edildiği söylenmekte ve iletişim bilimcilerin kavramı olumsuz anlamlarından mümkün olduğu kadar soyutlayarak "çağdaş dünyanın kaçınılmaz bir gerçeği" olarak ele aldıkları belirtilmektedir (Bektaş, 2002: 188).

19. yüzyıl devlet ve devlet erkini elinde tutanlar açısından bir dönüm noktası olarak kabul edilebilir. Yönetenlerin sadece şartlar gerektirdiği zaman değil, her an kamuoyunun desteğini almaları gerektiğini anlamaları, propagandaya siyasal iktidarlarının vazgeçilmez bir pratiği olarak değer vermeye başlamalarına yol açmıştır. 20. yüzyıl ise çağdaş anlamda propaganda kavramının kullanılmaya başlandığı dönemdir. Bu dönemde propaganda, ideolojinin aktarım aracı olarak görülmektedir (Akarcalı, 2003: 15-16). Bu açıdan bakıldığında modern yönetim anlayışında propagandanın, egemen düşünce yapılarının ve yönetsel düşünce sistemlerinin kamuoyuna aktarılması yönünde bir araç olduğunu söylemek mümkündür.

Günümüzdeki uygulamalara bakıldığında ise, propagandanın çok daha geniş alanlara yayıldığını söylemek mümkündür. En temel amaçlar aynı kalmakla birlikte uygulama anlamında bugün pek çok farklı noktaya temas edilmektedir. Özellikle günümüzde gazete, dergi, sinema, radyo ve televizyon gibi araçlara ek olarak, internet ile siyasal reklam, reklam, halkla ilişkiler, pazarlama gibi pek çok uygulama, propagandanın farklı bir boyutu olarak değerlendirilmektedir (Akarcalı, 2003: 9, Bektaş, 2002: 98-122). Buna göre propagandacılar ile halkla ilişkiler uzmanları gibi kimseler, kamuoyunun oluşturulması ve biçimlendirilmesinde kullanılan, iktidarı "sevimli ve haklı" göstermekle görevli kimseler olarak görülmektedir (Mills, 1974: 442). Bu açıdan bakıldığında tarihsel süreçte propaganda faaliyetlerinin uygulanma biçimlerinde büyük değişimlere rastlandığını söylemek mümkün olmaktadır. 
Günümüzde, "propaganda ve kitle iletişim araçları arasında yakın bir ilişki" (Akarcalı, 2003: 17) bulunmaktadır. Bu açıdan medya, propagandanın temel araçlarından biri olarak değerlendirilir hale gelmiştir. İletişim araçları ile kitlelerin yönlendirilmesine yönelik ilişkiye Mills (1974: 427428) de dikkat çekmekte ve siyasilerin ya da iktidar sahiplerinin bu araçlar vasıtasıyla yüzlerini görmedikleri ya da hiç görmeyecekleri milyonlara ulaşabildiklerini belirtmektedir. Aynı zamanda bu durumun, kamuoyunun pasifleştirilerek, kendilerine telkin edilenlere uymak zorunda kalan topluluklara indirgenmesine yol açığını da açıklamaktadır. Mills'in ifadesiyle iletişim araçları "servet ve iktidar sahibi seçkinlerin en önemli iktidar araçlarından biri" (1974: 442) olarak değerlendirilmektedir.

İletişim araçlarının günümüzdeki kullanım yoğunluğu, oranı ve etkisinin küresel boyutları göz önünde bulundurulduğunda, propaganda kapsamındaki çalışmalar açısından önemini ve iktidarlar için ne ifade ettiğini anlamak zor değildir. Aynı zamanda medyada yer alan haberler ve bu haberlerin oluşturulma biçimleri de propaganda açısından farklı bir önem taşımaktadır. Özellikle kamuoyu yoklamaları, piyasa araştırmaları, haber ve imaj yönetimi gibi stratejik iletişim teknolojileri, haberi, olayların kayıt altına alınması olmaktan çıkararak, iktidar mücadelesinde politikacıların ve halkı birbirine bağlayan siyasi süreçlerin yapı taşı haline getirmiştir. Bu açıdan "her ülkede haber o ülkenin sosyal, kültürel, ekonomik ve siyasi şartları tarafından" şekillendirilen ve sınırlandırılan (Bennett, 2000: 29, 38) bir unsur haline gelmiştir.

Medya ve propaganda arasındaki ilişki Chomsky ve Herman tarafından ortaya konulan "Propaganda Modeli"nde de kendisini göstermektedir. Buna göre, özellikle ADB medyasındaki hakim görüşün "nasıl ve neden işleyebildiğini anlamak ve çözümlemek amacıyla" (Herman, 2003: 223) ortaya konulan model, özellikle medya ile propaganda arasındaki ilişkiye odaklanmaktadır.

Propaganda modeli temelde, Herman'ın açıklamasıyla "pazar sistemine gömülmüş" medya gerçeğine ışık tutmakta ve medyanın işletmeler, şirketler ile reklamcılar tarafından finanse edilen ve hükümete ve büyük şirkete bilgi kaynağı açısından bağı (Herman, 2003: 224) olan bir araç olmasından yola çıkarak medya yapısının analizine dayanmaktadır. Herman ve Chomsky (2006: 15)'e göre medya, "kendisini denetleyen ve finanse eden güçlü toplumsal grupların çıkarlarına hizmet eder ve onların lehine propaganda yapar". Özellikle belirttikleri gibi güç manivelalarının devletin elinde bulunduğu ülkelerde resmi sansür aracılığıyla medya üzerinde denetim kurulmakta ve medyanın hakim grubun çıkarlarına hizmet ettiği açıkça görülmektedir. Ancak medyanın özel sermayede bulunduğu ve resmi sansürün uygulanmadığı yerlerdeyse açık bir biçimde propaganda uygulamalarını görmek daha zordur (Herman ve Chomsky, 2006: 81). Buna göre, totaliter rejimlerde haber, yöneticiler tarafından düzenli olarak sansürlenebilmekte iken, Batı demokrasilerinde uygulanmaya çalışılan açık müdahaleler ve kontroller doğrudan kamuoyunun tepkisi ile karşılaşmaktadır (Pratkanis ve Aronson, 2008: 314). Bu nedenle demokrasilerde medya üzerinde kurulmaya çalışılan denetimler, daha örtük bir biçimde sürdürülmektedir.

Herman ve Chomsky (2006: 75), Lippmann'ın "rızanın imalatı" kavramına da gönderme yaparak, rızanın imalatı sürecinde propagandanın önemli bir rolü olduğunun yaygın bir kabul olarak görüldüğünü söylemekte ve aynı zamanda Lippmann'ın propagadanın "hükümetin düzenli bir organı" olarak işlev gösterdiğini savunduğunu belirtmektedirler. Bu açıdan "kitle medyasının bütün yaptığının bundan ibaret olduğunu iddia etmiyoruz, ama verdikleri hizmetin bütünü içerisinde propaganda işlevlerinin önemli bir yer tuttuğuna inanıyoruz" diyen Herman ve Chomsky (2006: 75) çalışmalarında bu işlevin nasıl gerçekleştiğini açıklamaya çalışmışlar ve bu amaçla haberi şekillendiren beş süzgeç üzerinde durmuşlardır.Bu süzgeçler sırasıyla; 
•Kitle medyasının büyüklüğü, mülkiyeti ve kar yönelimi,

•İs yapmak için reklamcılık ruhsatı,

•Kitle medyasının haber kaynakları,

•Tepki üretimi ve zorlayıcılar,

-Bir denetim mekanizması olarak anti-komünizm (Herman ve Chomsky, 2006: 81-115) olarak ele alınmaktadır.

Bu süzgeçlerden geçen haber, kamuoyuna iletilmeye hazır hale gelmektedir. Buna göre Herman ve Chomsky'nin (2006: 81) açıkladığı gibi “Propaganda Modeli” basılmaya uygun haberlerin nasıl süzgeçten geçtiğini, muhalefetin marjinalleştirilmesini ve özel çıkar gruplarının mesajlarının halka nasıl iletildiğini ortaya çıkarmayı amaçlamaktadır. Sonuç olarak tüm bu süzgeçler Herman ve Chomsky'nin ifadesiyle "neyin haber değeri taşıyıp taşımadığını" tanımlamakta ve "propaganda kampanyalarına dönüşen süreçlerin temellerini ve işleyişlerini" (2006: 82) açıklamaktadır.

Haberin oluşturulması süreci kadar yayınlanacak haberlerin seçimi süreci de medyanın propaganda işlevleri açısından değerlendirilmelidir. Bu açıdan "haber seçiciliği propagandanın başlangıcıdır” diyen Pratkanis ve Aronson (2008: 312)'a göre herhangi bir günlük gazete potansiyel haberlerin $\% 75$ 'ini reddetmekte ve bu haberleri asla yayınlamayarak geri çevirmektedir. Böylece medyanın haberi nasıl sunduğu kadar, neyi haber olarak sunmayı tercih ettiği sorunu da gündeme gelmektedir.

Özellikle son yıllarda iletişim araçlarında yaşanan dönüşüm de medya ile propaganda arasındaki ilişkinin farklı açılardan tartışılmasını mümkün kılmıştır. Buna göre, iletişim teknolojisinde yaşanan önemli gelişmeler; bilgi ve enformasyonun üretim, dağıtım ve tüketim süreçlerinde büyük değişikliklere, dönüşümlere yol açmış ve radyo, gazete, televizyon ve sinema gibi kitle iletişim araçlarının fiziksel engelleri aşarak kitlelere erişme imkanları doğrultusunda propaganda faaliyetleri açısından önemli potansiyel içerdiği anlaşılmıştır. Kitle iletişim araçları ile kitleleri fiziksel olarak bir araya getirmeden bir arada tutabilme olanağı doğmuştur (Bektaş, 2002: 5758). Son yıllarda ise özellikle yeni iletişim teknolojilerinde ve internette yaşanan gelişimler ve ilerlemeler medyanın kullanımına ilişsin tartışmaları farkı alanlara da taşımıştır.

İletişim teknolojilerinde meydana gelen değişimler toplumda elde edilebilen enformasyon miktarını genişletmiş, aynı zamanda da enformasyonu herkes için ulaşılabilir kılmıştır. Böylece kitle kavramı üzerine yeniden düşünüldüğü bir döneme geçilmiş ve izleyicinin, mesajın üreticisine dönüştüğüne yönelik bakış açıları geliştirilmiştir. İletişim araçlarında yaşanan gelişimler, kamusal tartışmaların doğrudanlaşmasına neden olarak, eşitsizlikçi iletişim ortamları sorununa çözüm gibi görünse de bu gelişmeler aslında, farkı dinamikleri de içinde barındırmakta ve demokratik işlevleri açısından da sorgulanmaktadır (Timisi, 2003: 9-11). Bu açıdan bakıldığında yeni iletişim teknolojileri ile hem iletişim araçlarının kullanım biçiminde hem de medya içeriklerinin oluşturulması sürecinde yaşanan değişimler, bir yandan demokratik katılımı mümkün kıldığı söylemi üzerinden açıklanmaya çalışılmakta bir yandan da yeni eşitsizlikler ve yeni iktidar biçimleri yaratması açısından eleştirilmektedir. Özellikle internet, "yeni dünya düzeninde mevcut eşitsizlikleri derinleştiren bir teknoloji olarak kavramsallaştııılmaktadır”. Buna göre, liberal bakış açısı içerisinden yeni iletişim teknolojilerinin farklı özgürlük alanları yarattığı kabul edilse de 
eleştirel bakış, bu teknolojilerin yeni egemenlik ve iktidar alanı ve işleyişi yaratmaya elverişli olduğu noktasında konuyu tartışmaktadır (Timisi, 2003: 211, 227). Ancak tüm bu tartışmalar bu çalışmanın kapsamı içinde değerlendirilemeyecek derecede geniştir. Bu nedenle ortaya çıkan yeni dinamiklerin ve yeni iletişim teknolojilerin propaganda ve medya arasındaki ilişkiyi farklı ve geniş bir yelpazeye taşıdığı da unutulmamalıdır.

Sonuç olarak her yönetim biçiminin ve her iktidarın, varlığını sürdürebilmesi ve koruyabilmesi açısından temel meşruiyet aracı olan propaganda, farklı yöntemler ve araçlarla uygulanmakla birlikte, iktidarın varlığının devamlıı̆ı açısından gerekmektedir. Buna göre özellikle baskı ve zora dayanmayan görece demokratik toplumların işleyişini sağlamak, bireylerde rızanın oluşturulması amacına hizmet eden örtük propaganda faaliyetleri ile mümkün olabilmektedir.

\section{Sonuc}

Yöneten ve yönetilen ayrımının varlığı sonucunda gücün, iktidarın ve otoritenin kurulması ve sürdürülmesi çabası iktidarları, özellikle demokratik toplumlarda farklı çözüm arayışlarına yönlendirmiş ve baskıya karşı direnç gösteren toplumlarda iktidarın sürdürülmesi yeni bir sorun olarak ortaya çıkmıştı. Buna göre totaliter yönetimlerin aksine, baskı ve şiddetin işlevini yitirdiği demokratik toplumlarda iktidar ancak, kamuoyunun rızasını alması ve meşruiyetini oluşturması sayesinde varlık gösterebilmektedir. Özellikle sivil alanın görece geniş olduğu toplumlarda baskıcı ve dayatmacı tutumlar yerini, rızanın ve hegemonyanın oluşturulmasını amaçlayan uygulamalara bırakmaktadır. Bu süreçte ise örtük ya da açık propaganda faaliyetleri ile bu faaliyetler amacıyla kullanılan iletişim araçları toplumsal alanda önemli rol oynayan öğeler haline gelmişlerdir. Özellikle meşruiyetin süreklilik arz eden bir durum olmaması ve sürekli olarak yeniden inşa edilmesi gerekliliği, günümüz propaganda faaliyetlerinin sistemli bir biçimde devamlıı̆ını zorunlu kılmıştır. Bu doğrultuda iletişim araçları bir yandan geniş kitlelere erişebilmeleri bir yandan da kamuoyunda etkili araçlar olmaları nedeniyle iktidarların, propaganda amacıyla kullandıkları araçlar olarak işlev görmektedirler. Buna göre tarihsel süreçte ortaya çıkışından farklı olarak günümüzde reklam, halkla ilişkiler, pazarlama ile televizyon, gazete, radyo, sinema, internet gibi pek çok alanı ve aracı da içinde barındıran propaganda uygulamaları günümüzde, iktidarların varlıkları sürdürebilmeleri ve otoritelerinin devamlılığını sağlayabilmeleri için kaçınılmaz bir olgu olarak değerlendirilebilmektedir. 


\section{Kaynakça}

Akarcalı, Sezer (2003). 2. Dünya Savaşında İletişim ve Propaganda. Ankara: İmaj.

Althusser, Louis (2010). İdeoloji ve Devletin İdeolojik Aygıtları. Çev. Alp Tümertekin. İstanbul: İthaki.

Anderson, Perry (2007). Gramsci Hegemonya Doğu-Batı Sorunu ve Strateji. Çev. Tarık Günersel. İstanbul: Salyangoz.

Bektaş, Arsev (2002). Siyasal Propaganda: Tarihsel Evrimi ve Demokratik Toplumdaki Uygulamaları. İstanbul: Bağlam.

Bennett, W. Lance (2000). Politik illüzyon ve Medya. Çev. Seyfi Say. İstanbul: Nehir.

Biber, Ayhan (2003). "Bir Meşrulaştırım Yöntemi Olarak Halkla İlişkilerin Meşruiyeti" Amme İdaresi Dergisi. Cilt 36 Sayı 4 Aralık; 43-53.

Buci-Glucksmann, Christine (2012). "Hegemonya ve Rıza: Politik Bir Strateji” Gramsci'ye Farklı Yaklaşımlar. A. Showstack Sassoon (der.) içinde. 121-133, Ankara: Dipnot; 121-133.

Chomsky, Noam (2003). "Propaganda ve Kamusal Aklın Kontrolü" Kapitalizm ve Enformasyon Çağı: Küresel İletişim Devriminin Politik Ekonomisi. R.W. McChesney vd. (ed.) içinde, Ankara: Epos; 209-222.

Chomsky, Noam (2008). Medya Denetimi. Çev. Elif Baki, İstanbul: Everest.

Crehan, Kate (2006). Gramsci Kültür Antropoloji. Çev. Ümit Aydoğmuş, İstanbul: Kalkedon.

Çetin, Halis (2003). "Siyasetin Evrensel Sorunu: İktidarın Meşruiyeti-Meşruiyetin İktidarı" Ankara Üniversitesi SBF Dergisi 58/3; 61-88.

Duverger, Maurice (2011). Siyaset Sosyolojisi. Çev. Şirin Tekeli, İstanbul: Varlık.

Forti, Augusto (2000). Bilim ve İktidar. Çev. Mehmet KÜÇÜK, Ankara: Tübitak.

Friedman, Richard B. (1990). "On the Concept of Authority in Political Philosophy" Authority. Raz, Joseph (der.), New York: New York University Press.

Galbraith, John Kenneth (2004). İktidarın Anatomisi. Çev. Ramazan Diker, Ankara: Hece.

Gramsci, Antonio (2009). Hapishane Defterleri. Çev. Kenan Somer, Ankara: Aşina.

Gürbüz, Ahmet (1998). Hukuk ve Meşruluk (Evrensel Erdem Üzerine Bir Deneme). İstanbul: Beta.

Hall, Stuart; Lumley, Bob ve McLennan, Gregory (1985). Siyaset ve İdeoloji Gramsci. Çev. Sadun Emrealp, Ankara: Birey ve Toplum. 
Herman, Edward S. (2003). "Propaganda Modeline Dönüş" Kapitalizm ve Enformasyon Çağı: Küresel İletişim Devriminin Politik Ekonomisi. R.W. McChesney vd. (ed.) içinde, Ankara: Epos; 223-240.

Herman, Edward S.; Chomsky, Noam (2006). Kitle Medyasının Ekonomi Politiği Rızanın İmalatı. Çev. Ender Abadoğlu, İstanbul: Aram.

Kapani, Münci (1998). Politika Bilimine Giriş. İstanbul: Bilgi.

Kazancı, Metin (2002). "Althusser, İdeoloji ve İletişimin Dayanılmaz Ağırlığı” Ankara Üniversitesi SBF Dergisi 57/1; 55-88.

Lodziak, Conrad (2003). İhtiyaçların Manipülasyonu Kapitalizm ve Kültür. Çev. Berna Kurt, İstanbul: Çitlembik.

Morton, A. David (2011). Gramsci'yi Çözümlemek. Çev. Barış Baysal, İstanbul: Kalkedon.

Mills, Wright (1974). İktidar Seçkinleri. Çev. Ünsal Oskay, Ankara: Bilgi.

Pflaum, Dieter ve Pieper, Wolfgang (1993). Lexikon der Public Relations. Regensburg: Moderne Industrie.

Pratkanis, R. Anthony ve Aronson, Elliot (2008). Propaganda Çağı İknanın Gündelik Kullanımı ve Suistimali. Çev. Nagihan Haliloğlu, İstanbul: Paradigma.

Şengül, H. Tarık (2012). “iktidar” Siyaset Bilimi: Kavramlar, İdeolojiler, Disiplinler Arası Iliş̧iler. Gökhan Atılgan ve E. Atilla Aytekin (haz.) içinde ss. 41-53. İstanbul: Yordam.

Tolan, Barlas (1996). Toplum Bilimlerine Giriş. Ankara: Adım.

Timisi, Nilüfer (2003). Yeni İletişim Teknolojileri ve Demokrasi. Ankara: Dost.

Yetiş, Mehmet (2012). "Hegemonya” Siyaset Bilimi: Kavramlar, İdeolojiler, Disiplinler Arası Ilişkiler. Gökhan Atılgan ve E. Atilla Aytekin (haz.) içinde, İstanbul: Yordam; 87-98.

Yüksel, Erkan (2007). “'Kamuoyu Oluşturma' ve 'Gündem Belirleme' Kavramları Nerede Kesişmekte, Nerede Ayrılmaktadır?" Anadolu Üniversitesi Sosyal Bilimler Dergisi 7(1): 571-586. 